\title{
9. Capital punishment at the intersections of discrimination and disadvantage: the plight of foreign nationals
}

\author{
Carolyn Hoyle
}

Around the world, differential rates and experiences of victimization, criminalization and punishment can be largely accounted for by race, religion and citizenship. ${ }^{2}$ Death sentences and executions are extreme examples of the effects of disempowerment, disadvantage and discrimination on certain populations subject to the criminal process. While some groups recognized as vulnerable — such as juveniles, pregnant women or the intellectually disabled — are in most countries excluded from the ultimate penalty by categorical exemptions, characteristics such as race, religion and citizenship status are not protective and are sites of discrimination in the administration of the death penalty. Furthermore, these characteristics can interact with each other to create a sum of disadvantage greater than its parts.

To date, most research on the death penalty has been conducted in the US and has focused on discrimination on grounds of race, although empirical research has also demonstrated the adverse impact of inadequate resources. ${ }^{3}$ Much less attention has been paid to factors such as religion, citizenship, gender and sexual orientation. Beyond the US, there is a paucity of empirical data on jurisdictions that make regular use of the death penalty, especially those that rely on migrant workers. This chapter will focus on under-researched countries in the Gulf and Asia, particularly Saudi Arabia, the United Arab Emirates (UAE), Pakistan, Malaysia and Indonesia. In such jurisdictions, we learn little by focusing only on race. There, it will be argued, discrimination and arbitrariness in the administration of the death penalty would be better understood in relation to disadvantage at the intersections of ethnicity, religion and citizenship.

In considering these under-researched sites of discrimination and disadvantage, this chapter adopts an intersectionality approach, turning the lens on foreign nationals who do not enjoy

1 In places, this chapter draws on research conducted for Roger Hood and Carolyn Hoyle, The Death Penalty: A Worldwide Perspective (5th edn, OUP 2015). Thanks to Saul Lehrfreund of the Death Penalty Project and Maya Foa of Reprieve for information on cases and campaigns; to Laura Tilt for research assistance; and to David Rose for comments on an earlier draft.

2 See, for example, RJ Miller and A Alexander, 'The Price of Carceral Citizenship: Punishment, Surveillance, and Social Welfare Policy in an Age of Carceral Expansion' (2016) 21 Michigan J Race \& L 2, 291-314.

3 Socio-economic disadvantage can have a significant impact on the likelihood of prosecutors seeking the death penalty and on juries sentencing a defendant to death, both decisions influenced by the effectiveness of legal counsel (with under-resourced state appointed attorneys less likely to be able to protect their clients from the ultimate penalty). Roger Hood and Carolyn Hoyle, The Death Penalty: A Worldwide Perspective (5th edn, OUP 2015) ch 7; see also American Civil Liberties Union, 'Slamming the Courthouse Door: Denial of Access to Justice and Remedy in America' (2010) <www.aclu.org/ slamming-courthouse-doors-denial-access-justice-and-remedy-america> accessed 17 November 2018. 
the benefits of citizenship in an era when 'more and more people are on the move worldwide, [and] legal and philosophical questions about belonging have come to define our era'. ${ }^{4}$ It is argued that foreign nationals, whether migrant workers, asylum-seekers, trafficked persons or those who have temporarily crossed a border for other, disparate reasons, are especially vulnerable to the death penalty. They do not enjoy the same legal and social protections, and they are at risk of organized crime, particularly trafficking. They typically lack power, resources and access to support networks and are subject to suspicion, over-policing, criminalization and discrimination in the criminal process. In some jurisdictions, Bosworth explains in relation to the UK, '[f]ears about economic migration merged seamlessly with narratives about terrorism and radicalization, constructing foreign national offenders as fundamentally unwelcome and always, already, potentially dangerous'. ${ }^{5}$

Meanwhile, in an international environment characterised by fear of Islamic terrorism, certain states are asserting their sovereign right to choose punishments that they believe will deter the worst crimes and to reject the rising discourse around human rights for all. Such fears create the conditions whereby the death penalty is experienced unequally by those suspected of having committed serious crimes, however defined. States compound the disadvantage already experienced by certain populations by decisions about which crimes should be subject to the death penalty and whether to impose religious laws that might impact certain communities adversely. Evidence of discrimination raises the question of what measures those states should take to ameliorate disadvantage. Hence, the final section of this chapter considers the positive obligations of states to assist foreign nationals on death row, whether they be people caught up in trafficking networks or religious minorities charged with terrorist offenses.

\section{LIVES THAT DO NOT MATTER: DISCRIMINATION IN THE GLOBAL DEATH PENALTY}

Over the past half-century, the mandatory death penalty has come under sustained attack in North America, the Caribbean and common law Africa. ${ }^{6}$ Developments in international jurisprudence indicate that international standards have become firmly set against the mandatory imposition of capital punishment, and those countries which maintain it are in breach of a widely accepted human rights norm. Yet the abolition of mandatory sentences has not, and cannot, fully resolve the problem of inequity or disproportionality in the administration of capital punishment. For when the death penalty is not mandated for a crime, it inevitably introduces considerable discretion into sentencing decisions. In other words, whether the death penalty is mandatory or discretionary, arbitrariness and discrimination remain. Decision-making within discretionary systems is likely to be influenced by prejudice against people on the grounds of their race, religion or citizenship, with 'non-citizens' particularly disadvantaged.

\footnotetext{
4 A Aliverti and M Bosworth, 'Introduction: Criminal Justice Adjudication in an Age of Migration' (2017) 20 New Crim L Rev 1, 2.

5 M Bosworth, 'Penal Humanitarianism? Sovereign power in an era of mass migration' (2017) 20 New Crim L Rev 39, 44.

6 A Novak, The Global Decline of the Mandatory Death Penalty (Routledge 2014).
} 


\section{EVIDENCE ABOUT RACIAL AND RELIGIOUS DISPARITIES}

The US Supreme Court held in Furman v Georgia ${ }^{7}$ that the American death penalty was, as administered, unconstitutional, not only because it was imposed arbitrarily, but also inequitably depending upon the race of the defendant. Afterwards, it was assumed that new statutes, whose constitutionality was affirmed by the Supreme Court in the Gregg decision of $1976,{ }^{8}$ would eliminate racial bias. ${ }^{9}$ They did not. Rigorous empirical studies conducted since then have provided evidence of the influence of the race of defendants and, particularly, the race of victims in prosecutors' decisions to seek death and juries' decisions to impose it. ${ }^{10}$

We know much less about jurisdictions beyond the US, but there is evidence that countries within Africa that have at times been ruled by a white majority have also seen racism in their justice systems. In South Africa, the application of the death penalty reflected biases against ethnic minorities. In the early part of the twentieth century, 'the heaviest burden of capital punishment fell on poor white South Africans or those of Indian or mixed-race descent'. Later, capital punishment was applied predominantly to the black majority by the white-controlled state. ${ }^{11}$ As in the American south, cases where a black man had (allegedly) raped a white woman were almost never reprieved. As Novak notes, such cases 'served the purposes of racial self-defense'. ${ }^{12}$

It might be expected that former colonies would remain racially divided in the post-colonial period along the same racial lines. However, in some ex-colonies, it is religious and other minorities who now face discrimination. India reserves the death penalty for the most serious cases, under the 'rarest of the rare' doctrine. This should be governed by objective factors: the heinous nature of the offense and the potential for rehabilitating the offender. In practice, it has contributed to the arbitrary and unequal application of the death penalty. A study by Delhi's National Law University of 373 of the 385 prisoners under sentence of death in India by Project 39A found that almost three quarters of death row prisoners were 'economically vulnerable', and over three quarters belonged to 'backward classes and religious minorities', so demonstrating the 'disparate impact of the death penalty on marginalised and vulnerable groups'. ${ }^{13}$

However, discrimination cannot simply be blamed on colonialist or post-colonialist policies, although in some countries they have played a part. ${ }^{14}$ Around the retentionist world, those belonging to religious and other minority groups are frequently exposed to higher risks of criminalization and the death penalty. Indeed, in some countries, religious beliefs, conversion from one religion to another, atheism and even the academic study of religion can

Furman v Georgia 408 US 238 (1972).

Gregg v Georgia 428 US 153 (1976).

9 For thorough and persuasive analysis of constitutional regulation of capital punishment in the US, see CS Steiker and JM Steiker, Courting Death: The Supreme Court and Capital Punishment (Belknap Press 2016).

10 For a review of rigorous empirical evidence on this point, see Hood and Hoyle (n 3 ) ch 8.

11 Novak (n 6) 127-128.

12 ibid 128.

13 National Law University, Delhi, 'Death Penalty India Report, Summary' (6 May 2016) <www .project39a.com/dpir> accessed 17 November 2018.

${ }_{14}$ C Cunneen, 'Postcolonial Perspectives for Criminology' in M Bosworth and C Hoyle (eds), What is Criminology? (OUP 2011) ch 17. 
result in a death sentence. ${ }^{15}$ While we know something about racial and religious disparities in retentionist jurisdictions around the globe, little attention has been paid to discrimination and disadvantage experienced by those - particularly minorities - who find themselves accused of serious offenses on foreign soil. Foreign nationals therefore provide something of a case study of disadvantage at the intersections of race, religion and citizenship.

\section{AN INTERSECTIONAL APPROACH TO DISCRIMINATION AGAINST FOREIGN NATIONALS}

Economic globalization has created the conditions whereby there are more migrant workers than ever; currently about 232 million migrants ${ }^{16}$ (over 3 percent of the global population). ${ }^{17}$ 'As unprecedented levels of human mobility continue to define our era, criminal justice institutions in countries around the world are increasingly shaped by mass migration and its control.' ${ }^{18}$ While often making a positive contribution to the economies of host countries, migrants typically enjoy few protections and are vulnerable not only to trafficking and other forms of victimization, but also to harsh punishments if they are convicted of certain criminal offences. It is crucial, therefore, to understand states' responses to foreign nationals for the wider theorization of penal power. ${ }^{19}$ A white, professional academic migrating from the US to Australia to take up a post at another university would be unlikely to end up in custody or detention, facing criminal charges. A Pakistani national migrating to Saudi Arabia to perform menial work without the appropriate paperwork would be much more vulnerable. Often, citizenship is racialized. Those with the power to secure and defend citizenship are in a position of advantage over, for example, non-White people from post-colonial societies. ${ }^{20}$ What is becoming apparent in both theoretical and empirical work that adopts this approach, is the importance of power, the recognition that 'structural inequalities and power relationships

15 UN Human Rights Council, 'Capital Punishment and the Implementation of the Safeguards Guaranteeing Protection of the Rights of those Facing the Death Penalty' A/HRC/30/18 (16 July 2015) 11-12; recent international press coverage of the case of Asia Bibi, sentenced to death in Pakistan for blasphemy in 2010, has highlighted discrimination against religious minorities, such as Christians, in Muslim-majority countries, though most of those who are subject to blasphemy laws are Muslims (Asia Bibi was acquitted and released from prison in November 2018: 'Pakistan Blasphemy Case: Asia Bibi Freed from Jail' (BBC News, 8 November 2018) <https://www.bbc.co.uk/news/world-asia-46130189> accessed 16 June 2019 .

16 The International Organization for Migration defines a migrant as any person who is moving or has moved across an international border or within a State away from his/her habitual place of residence, regardless of (1) the person's legal status; (2) whether the movement is voluntary or involuntary; (3) what the causes for the movement are; or (4) what the length of the stay is. International Organization for Migration, 'Who is a Migrant' <www.iom.int/who-is-a-migrant> accessed 20 August 2017. Since the start of the new millennium, international migration has risen by about $41 \%$. United Nations, 'Trends in International Migration, 2015 Population Facts' (cited in Aliverti and Bosworth (n 4) 2).

17 International Labour Organization, 'International Labor Standards on Migrant workers' <www .ilo.org/global/standards/subjects-covered-by-international-labour-standards/migrant-workers/lang--en/ index.htm> accessed 17 November 2018.

18 Aliverti and Bosworth (n 4) 1.

19 ibid 2.

20 J Chacon, 'Overcriminalizing Immigration' (2012) 102 J of Crime, L \& Criminology 613. 
shape which combination of identities matter in what particular contexts' ${ }^{21}$ Race is not the only characteristic that provides power. Nationality, religion, socio-economic status, criminal record and personal contacts are all also correlated with ease of access in most spheres of life; the border is no exception. But these characteristics do not simply add up. They intersect to produce a weight of disadvantage that may well be qualitatively greater than its parts.

In recent decades, some criminologists have sought to move beyond incorporating race, class, gender and other sites of disadvantage into their scholarship, and to theorize about the intersections of those factors in research on crime, victimization and criminal justice. The main point of intersectionality is to recognize that lived experiences cannot be fully understood solely by reference to distinct identities, such as female or Muslim. Rather, these identities overlap and 'intersect' in various ways depending on the time or other context. ${ }^{22}$ They are multiplicative and interactive, rather than simply additive.$^{23}$ Of relevance here are the ways in which 'the justice system embodies, perpetuates, and transforms existing social inequalities such as race, class, and gender' ${ }^{24}$ Kimberlee Crenshaw's work on intersectionality focused on violence against women of color, hence race and gender were key areas of focus. However, she was alive to the impact of both economic and immigration status on women's experiences, and more recently, scholars working on migration have further developed this theoretical approach.

'[S]ocial, cultural and demographic change over the last two decades', with increasing migration across borders, 'has reconfigured the boundaries of the race and crime debate as originally conceived'. ${ }^{25}$ Meanings of race and ethnicity have altered and with that has arisen the need to reassess old concepts and theories. It is no longer sufficient to focus only on race as a defining category of discrimination; we must now recognize the relevance of relationships of power and domination between the state and marginalized groups that are based as much on socio-economic disadvantage, religion, identity and citizenship as on racial prejudice, particularly in death penalty scholarship beyond the US. ${ }^{26}$ Within the UK-not, of course, a capital punishment jurisdiction - scholarship has demonstrated the vulnerability and ontological insecurity of those with precarious migration status, on whom the powers of the criminal law and criminal justice policies are focused. ${ }^{27}$ For example, Zedner has argued that governments have harnessed the 'territorially bounded concept' of citizenship to respond to a perceived threat to national security from 'noncitizens' or 'irregular citizens' who are 'deemed to stand outside

21 L Paik, 'Critical perspectives on intersectionality and criminology: Introduction' (2017) 21 Theo Crim 4, 6 .

22 K Crenshaw, 'Mapping the Margins: Intersectionality, Identity Politics, and Violence Against Women of Color' (1991) 43 Stan L Rev 1241.

23 M Baca Zinn and BD Thornton, 'Theorizing Difference from Multiracial Feminism' (1996) 22 Feminist Studies 321.

24 Paik (n 21) 4.

25 C Phillips and C Webster, 'Introduction: Bending the Paradigm - New Directions and New Generations' in C Phillips and C Webster (eds), New Directions in Race, Ethnicity and Crime (Routledge 2013) 6 .

26 ibid 8.

27 P Ramsay, The Insecurity State: Vulnerable Autonomy and the Right to Security in the Criminal Law (OUP 2012). 
of civil society'. ${ }^{28}$ The academy should draw on this work and find ways to explore migrants' experiences of justice in under-researched places.

This chapter does not present an intersectional analysis of the death penalty, as sufficient data are not yet available. ${ }^{29}$ But it asserts that an intersectional approach is necessary to fully understand the discriminatory application of the death penalty around the world. It makes a case for thinking intersectionally about the death penalty and considers some of the evidence available to demonstrate its importance. ${ }^{30}$

\section{THE DISPROPORTIONATE USE OF CAPITAL PUNISHMENT ON FOREIGN NATIONALS}

Foreign nationals, especially from Asia and Africa, are disproportionately affected by the death penalty. ${ }^{31}$ They might be migrant workers, people who are trafficked, asylum seekers, those who commit crimes while traveling abroad and those who cross borders to commit crimes - such as those who smuggle drugs or other prohibited goods.

It is estimated that nationals of at least 50 states are currently on death row or have recently been executed abroad..$^{32}$ For example, nearly 120 Nigerians are on death row in China, with more than 170 in Indonesia, Thailand, Malaysia and Vietnam. ${ }^{33}$ In 2016, of just over 1000 persons on death row in Malaysia, more than 400 were foreign nationals and of the 17 mandatory death sentences imposed for drug trafficking, seven were of foreign nationals. ${ }^{34}$ Furthermore, at least 250 Malaysians are under sentence of death abroad for drug offenses. ${ }^{35}$ Some states execute foreign nationals even while their governments repeatedly express concerns about the execution of their own citizens abroad. For example, in 2015, of 14 people executed in Indonesia, just two were Indonesian nationals; the others were from Australia,

28 L Zedner, 'Security, the State and the Citizen: the Changing Architecture of Crime Control' (2010) 13 New Crim L Rev 379, 381-382.

29 De Coster and Heimer argue persuasively for a mixed-method approach that can accommodate analysis of both the cultural and structural factors shaping experiences at the intersections of identity, as well as agency. S De Coster and K Heimer, 'Choice within constraint: An explanation of crime at the intersections' (2017) 21 Theo Crim 11.

30 For a related discussion on the need for further research that offers a 'thick description' of setting and political culture in the comparative study of the death penalty, see text accompanying nn 2-39 in Ch 13.

31 UN General Assembly, 'Report of the Special Rapporteur on Extrajudicial, Summary or Arbitrary Executions’ A/70/304 (7 August 2015) para 76.

32 UN Human Rights Council, 'Capital Punishment and the Implementation of the Safeguards Guaranteeing Protection of the Rights of those Facing the Death Penalty' A/HRC/30/18 1 r uly 2015) para 37.

33 UN General Assembly, 'Report of the Special Rapporteur' (n 31) para 77.

34 Amnesty International, 'Death Sentences and Executions 2016' (1 April 2017) 22 <www.amnesty .org/download/Documents/ACT5057402017ENGLISH.PDF> accessed 17 November 2018. As this beok gres to press, on 10 October 2018, the new Malaysian government declared its intention to abolish capital punishment, though the process has not formally begun. See 'Malaysia to Table Bill to Abolish the Death Penalty in Coming Parliament Session, Says its Law Minister' (The Straits Times, 10 October 2018) <https:/www.straitstimes.com/asia/se-asia/no-more-death-penalty-death-row-inmates-to -get-reprieve-malaysia-law-minister> accessed 16 June 2019.

35 UN General Assembly, 'Report of the Special Rapporteur' (n 31) para 76. 
Brazil, Ghana, the Netherlands, Nigeria and Vietnam. All executions were for drug trafficking, an offense that does not meet the international legal threshold of 'most serious crimes'. ${ }^{36}$ However, while Indonesia executed foreign nationals, Indonesian authorities were proactively supporting the approximately 229 Indonesian nationals under sentence of death abroad, the majority held in Saudi Arabia. Several had been convicted for drug trafficking, particularly in Malaysia, but some were women migrant workers accused of murdering their employers, in cases where they appear to have acted in self-defense while being raped. ${ }^{37}$

Capital cases in Kuwait often involve foreign migrant workers from Pakistan, India and other nearby countries. For example, in 2013 five men were hanged, none of whom were Kuwaiti nationals. ${ }^{38}$ An Afghan parliamentary delegation that visited Iran in 2010 was informed by the Iranian judicial authorities that out of more than 5630 Afghan citizens in Iranian prisons at the time, about 3000 were on death row, most on drug-smuggling charges. Another Afghan parliamentary delegation reported 2000 Afghans on death row in Iran in March 2013, with dozens executed in 2012 and $2013 .{ }^{39}$ The high rate of drug-related executions (over half of all those hanged in 2016 were for drug offenses) and discrimination against Kurdish people of the Sunni branch of Islam ${ }^{40}$ means that the death penalty in Iran is more likely to be applied to vulnerable groups both within Iran and from across her borders.

Drug offenses result in the execution of foreign nationals elsewhere. Research by the human rights charity Reprieve suggests that large numbers of migrant workers are facing the death penalty in Gulf states, estimating that 82 percent of death row inmates in the UAE are foreign nationals. ${ }^{41}$ Of those, just under two-thirds are from the Indian subcontinent; 23 percent from India, 29 percent from Pakistan and 9 percent from Bangladesh, all of whom are highly represented within the population of low-paid migrant workers in the UAE. ${ }^{22}$ Many were convicted of non-violent offenses; indeed, just under a third of death row inmates in the UAE are convicted of drug offenses and all of these are foreign nationals.

Although overall executions have declined in Singapore, and there have been some successful challenges to the mandatory death penalty, ${ }^{43}$ some of those on death row are foreigners and they are likely to be poorly educated, economically marginalized migrants from the wider

36 Amnesty International, 'Death Sentences and Executions 2015' (6 April 2016) $31<$ www.amnesty .org/download/Documents/ACT5034872016ENGLISH.PDF> accessed 17 November 2018.

37 ibid 32.

38 Amnesty International, 'Death Sentences and Executions 2014' (31 March 2015) $37<w w w$ .amnesty.org.uk/files/death_sentences_and_executions_2014_en.pdf $>$ accessed 17 November 2018.

39 FIDH, 'Iran/Death Penalty: A State Terror Policy, Special Update for the 11 th World Day Against the Death Penalty' (10 October 2013) <https:/www.fidh.org/en/region/asia/iran/death-penalty-in-iran-a -state-terror-policy-14075> accessed 15 June 2019.

40 In August 2016, 25 Sunni Kurdish prisoners were executed in Iran, having been sentenced to death by the Revolutionary Courts after trials lasting less than 15 minutes and without any possibility of a defense, and following investigations involving torture and forced confessions. 'Iran: Annual Report on the Death Penalty 2016' (Iran Human Rights, 3 April 2017) <https://iranhr.net/en/reports/18/> accessed 16 June 2019.

${ }^{41}$ Reprieve, 'Migrant Workers Case Theory Memo' (6 July 2016) (unpublished) (on file with the author).

42 ibid.

43 Since 2012, the death penalty has no longer been mandatory for certain categories of homicide where there is no intention to kill, nor for some drug offenses where specific tightly defined conditions are met. 
region, such as Jabing Kho, a Malaysian national who was executed in May 2016 for the murder of a construction worker. ${ }^{44}$ Other recent cases include that of Chijioke Stephen Obioha, a Nigerian national, and Devendran Supramaniam, a Malaysian, both executed in November 2016 for drug trafficking. ${ }^{45}$

Various reports have expressed concerns about the treatment of migrant workers in Saudi Arabia. ${ }^{46}$ It is estimated that there were slightly over 10 million foreign nationals living in Saudi Arabia in 2014, out of a total population of approximately 30 million. But while they comprise about a third of the population, foreign nationals - particularly migrant workers from disadvantaged backgrounds in Africa, the Middle East and Asia-accounted for almost half of the 2208 executions recorded between 1985 and 2015. ${ }^{47}$ In 2016, Saudi Arabia executed at least 154 people, and while 118 were Saudis, the others were from Bangladesh, Chad, Eritrea, Nigeria, Qatar, Syria, Iraq, Egypt, Ethiopia, Jordan, and, in particular, Yemen and Pakistan. A significant proportion were executed for terrorism and drug-related offenses. ${ }^{48}$ There remain over 200 people on death row in Saudi Arabia, with foreign nationals accounting for almost three quarters of them, most from Pakistan, but some from other parts of the Indian subcontinent, and most for drug offenses. ${ }^{49}$

The paucity of data on foreign nationals on death row means most currently available information comes from UN or NGO reports, newspaper articles, and human rights lawyers. Analysis of these sources suggests three main reasons for the disproportionate number of foreign nationals sentenced to death and executed in Asia and the Middle East, and particularly in two of the three countries responsible for the most executions in the world, outside of China ${ }^{50}$ - Iran and Saudi Arabia ${ }^{51}$ : the socio-economic, language and other practical disadvantages experienced by most foreign nationals suspected of committing crimes; the types of crimes that foreign nationals might be likely to have committed; and religious laws that can discriminate against foreign nationals sentenced to death. This, it seems, is intersectionality in action: a proposition that better data may eventually confirm.

44 Kirsten Han, 'On Death Row in Singapore' (Slate, 5 November 2015) <www.slate.com/articles/ news_and_politics/roads/2015/11/singapore_s_harsh_death_penalty_inside_the_fight_to_save_one man_from_the.html $>$ accessed 15 June 2019; 'Malaysian Hanged in Singapore After Final Appeal Rejected' (The Guardian, 20 May 2016) <www.theguardian.com/world/2016/may/20/malaysian-kho -jabing-to-hang-after-singapore-court-denies-final-appeal> accessed 15 June 2019.

45 Samantha Boh, 'Two Drug traffickers Hanged for Their Offences' (The Straits Times, 18 November 2016) <https:/www.straitstimes.com/singapore/two-drug-traffickers-hanged-for-their -offences $>$ accessed 15 June 2019.

46 See, for example, Gethin Chamberlain, 'Saudi Arabia's Treatment of Foreign Workers Under Fire After Beheading of Sri Lankan Maid' (The Guardian, 12 January 2013) <https://www.theguardian.com/ world/2013/jan/13/saudi-arabia-treatment-foreign-workers> accessed 15 June 2019.

47 Amnesty International, 'Death Sentences and Executions 2013' (17 March 2014) 39<https://www .amnesty.org/download/Documents/4000/act500012014en.pdf> accessed 17 November 2018.

48 Amnesty International, 'Death Sentences and Executions 2016' (n 34) 33.

49 Reprieve, 'Briefing on Migrant Workers and the Death Penalty in the United Arab Emirates and the Kingdom of Saudi Arabia (2016) (on file with the author).

50 China undoubtedly executes more people than any other country in the world, but the number is a state secret. In 2009, Amnesty International ceased publishing data on executions and death sentences in China, though figures are thought to be in the thousands.

51 In 2016, Iran, Saudi Arabia, Iraq and Pakistan accounted for approximately $87 \%$ of the world's executions. Amnesty International, 'Death Sentences and Executions 2016' (n 34). 


\section{PRACTICAL DISADVANTAGES}

Recent reports of the UN Secretary General have focused on foreign nationals facing the death penalty as an area of considerable concern, ${ }^{52}$ and in 2015, the Special Rapporteur on extrajudicial, summary or arbitrary executions noted:

Persons facing the death penalty abroad are often disadvantaged compared with nationals of the prosecuting State. They can be disproportionately and thus arbitrarily affected by the death penalty owing to unfamiliarity with the laws and procedures in the prosecuting State. They may also have limited access to legal aid and therefore inadequate or low-quality legal representation. They may be unable to understand the language in which proceedings are conducted. They are less likely to have a support network of family and friends. ${ }^{53}$

In the context of the UK, Aliverti has demonstrated the significant disadvantages experienced by migrants in the criminal process when they cannot speak English. Her research demonstrates that language difference intersects with race, class, gender and national origin as important dimensions of social hierarchies and inequalities. In this context, the inability to speak the dominant language becomes blameworthy and a tangible marker of difference. ${ }^{54}$

On death rows around the world, foreign nationals may be ignorant of their rights and even about their sentence, simply because they do not speak the language of their jailors. The London-based Death Penalty Project has examined the cases of some of the roughly 400 foreigners on death row in Malaysia. They are, it has found, imprisoned in a strange jurisdiction with little understanding of its legal system, and they lack the support of friends or family. Even those in a more privileged position, who may have access to resources and international campaigns to attract attention to their plight, can be disadvantaged by inadequate due process protections. Those held on death row in Indonesia - such as the remaining 'Bali Nine' and the British grandmother, Lindsay Sandiford - have similar experiences. Some do not have access to interpreters. Sometimes they are not informed of their execution date, as was claimed to be the case for the recently executed Myuran Sukumaran. ${ }^{55}$ Furthermore, even with the services of an interpreter, some defendants may be disadvantaged by a failure to translate verbatim. 'Instead of facilitating their effective participation, the presence of interpreters sometimes hinders it and frustrates the communicative endeavor. ${ }^{56}$

As of June 2016, 90 percent of Pakistan's total migrant population lived in Saudi Arabia, UAE and Oman. Over 1.5 million Pakistani nationals work in Saudi Arabia. They are generally unable to speak Arabic and have little knowledge of the criminal justice system there. Labour law should provide some protection: since 1969 every migrant worker is required to be under contract with and guaranteed by a sponsor, who is responsible for obtaining visas and other paperwork. Sponsors often employ recruitment agencies in workers' home countries. In

52 UN General Assembly, 'Report of the Special Rapporteur' (n 31 ) para 78.

53 ibid para 73; see also Amnesty International, 'Killing in the Name of Justice: The Death Penalty in Saudi Arabia' (25 August 2015) <https:/www.amnesty.org/download/Documents/ MDE2320922015ENGLISH.PDF> accessed 15 June 2019.

54 A Aliverti, 'Lost in Translation? Examining the Role of Court Interpreters in Cases Involving Foreign National Defendants in England and Wales' (2017) 20 New Crim L Rev 130, 135.

55 Sukumaran and Chan were executed in April 2015, ten years after they were convicted.

56 Aliverti (n 54) 151. 
Pakistan, such agents are registered as Overseas Employment Promoters (OEPs), regulated by the Bureau of Emigration and Overseas Employment. They are supposed to look out for the rights of migrants moving to Saudi Arabia, but research by the London-based human rights organization Reprieve suggests that the regulatory system is inadequate to prevent exploitation of migrant workers by OEPs. ${ }^{57}$

In August 2015, five Special Rapporteurs asked the High Commissioner for Human Rights to order a stay of execution for seven Pakistani death row inmates awaiting execution for drug offenses. ${ }^{58}$ All were from very poor, rural areas, all had families financially dependent on them, and all had paid for the promise of a 'job' and travel and visas to Saudi Arabia with OEPs, who, shortly before their departure to Saudi Arabia, tortured the individuals, forcing them to ingest drugs for the purpose of trafficking. ${ }^{59}$ In other words, a system set up to protect vulnerable migrant workers was key to their exploitation and ensuing death sentence.

Clearly, prisoners' economic status, level of education and access to legal, social and other resources directly affects their ability to effectively participate in criminal proceedings against them in death penalty cases, as in all other trials. These disadvantages increase prisoners' vulnerability, but the examples used here alert us to another source of disadvantage: the types of offenses most likely to be committed by foreign nationals.

\section{OFFENSES SUBJECT TO CAPITAL PUNISHMENT}

To conform with Article 6(2) of the International Covenant on Civil and Political Rights (ICCPR), retentionist jurisdictions should impose the death penalty only for 'the most serious crimes'. Of course, what is the 'most serious' of crimes is both culturally and historically contingent, and in practice the death penalty is more likely to be imposed on minority and otherwise disadvantaged groups, including non-citizens.

In 2011, the Inter-American Commission on Human Rights clarified its interpretation of 'the most serious crimes' to mean 'those that affect most severely the most important individual and social rights and therefore merit the most vigorous censure and the most severe punishment' ${ }^{60}$ In line with UN policy and human rights standards, many countries that retain the death penalty are moving to restrict its use to the 'worst of the worst' offenses and offenders. Two offenses may be considered to be at opposite ends of the 'seriousness' spectrum: drug offenses and terrorism, both of which are more likely to be committed by foreign nationals.

Approximately 1000 people are executed each year for drug offenses, with 33 countries retaining the death penalty for drug trafficking and/or drug possession, including 19 where

\footnotetext{
57 Reprieve, 'Migrant Workers Case Theory Memo' (n 41).

58 From 2014 to 2016, 39 Pakistani migrants were executed in Saudi Arabia.

59 Mandates of the Special Rapporteur on the independence of judges and lawyers; the Special Rapporteur on Extrajudicial, Summary or Arbitrary Executions; the Special Rapporteur on Torture and Other Cruel, Inhuman or Degrading Treatment or Punishment; and the Special Rapporteur on Trafficking in Persons, Especially Women and Children, Letter from Special Rapporteurs to the King of Saudi Arabia (Office of the High Commission for Human Rights, Ref UA, SAU 4/2015, 25 August 2015) on file with the author.

${ }^{60}$ I/A Comm'n on HR, 'The Death Penalty in the Inter-American Human Rights System: From Restrictions to Abolition’ OEA/Ser. L/V.II, Doc 68 (31 December 2011) 55.
} 
Islam is the predominant religion. ${ }^{61}$ Of these, only six countries - China, Iran, Saudi Arabia, Vietnam, Malaysia and Singapore - routinely execute drug offenders. There haveheen moves to reduce the use of the death penalty for drug trafficking in Singapore and Iran.6 [22) owever, elsewhere, drug-related executions are on the rise, including in Indonesia and China, which is of particular concern given the poor measures of police and judicial integrity and lack of fair trial norms in those countries.

A significant proportion of drug traffickers on death rows across South-East Asia and the Middle East are foreign nationals, simply because in many of those states drug offenses carry the death penalty. ${ }^{63}$ Reprieve estimates that most people facing execution in Saudi Arabia have been charged with drug offenses: 'Many are vulnerable drug mules, the poorest of the poor who are often forced at gun point, or even drugged, into ingesting illegal substances to be carried into the Gulf region. ${ }^{64}$

The example given above of Pakistani nationals forced by OEPs to ingest drugs and smuggle them into Saudi Arabia was a clear case of trafficking under article 3 of the 2000 United Nations Protocol to Prevent, Suppress and Punish Trafficking in Persons, Particularly Women and Children ('the Trafficking Protocol'). According to the UN, individuals who have been coerced into trafficking drugs should be considered victims of human trafficking. The Trafficking Protocol places responsibilities on signatories to identify and not to punish trafficked victims who have been compelled to take drugs across a border, but these obligations are not always well understood, and protections which should be afforded to trafficked persons are not always guaranteed. In particular, mandatory laws and policies in relation to drug trafficking, such as in Singapore, may prevent an assessment of whether the 'perpetrator' is in fact a victim of trafficking, or even whether coercion should be a mitigating factor.

Chacon shows that in the US, from their inception, 'international efforts to regulate trafficking have generated thorny questions about whether unauthorised cross-border migrants caught in exploitative working conditions should be treated as trafficking victims worthy of protections, or as violators of international sovereignty subject to punishment'. As she explains, 'how those questions are answered can determine in important ways how noncitizens fare in the criminal justice system ' ${ }^{65}$ There, she found, the goal of victim protection appeared subsidiary to the goal of prosecuting noncitizen traffickers and using anti-trafficking legislation as a de-facto form of migrant control. ${ }^{66}$ And of course, other sites of disadvantage intersect with citizenship; those migrants who do not fall within the parameters of the Protocol's definition of

${ }^{61}$ 'Sharia Law and the Death Penalty' (Penal Reform International, July 2015) <https://www .penalreform.org/resource/sharia-law-and-the-death-penalty/> accessed 19 November 2018.

$626+$ 'Iran Drug Execution Reform: A Slow Stumble Toward Normalcy' (Iran Rights, 16 March $2017)<$ http://blog.iranrights.org/iran-drug-execution-reform-a-small-step-toward-normalcy/> accessed 22 August 2017.

63 UN General Assembly, 'Report of the Special Rapporteur' (n 31 ) para 83.

64 Reprieve, 'Justice Crucified: The Death Penalty in Saudi Arabia' (14 October 2015) <https:// www.reprieve.org.uk/wp-content/uploads/2015/10/2015_10_14_PUB-Saudi-Arabia-DP-report.pdf> accessed 15 June 2019.

65 J Chacon, 'Human Trafficking, Immigration Regulation, and Subfederal Criminalization' (2017) 20 New Crim L Rev 96, 102.

66 ibid 108. 
trafficking may be at greater risk of drug trafficking charges due to their social and economic disadvantage. ${ }^{67}$

Countries which make regular use of the death penalty for drug offenses - such as Singapore and Iran-assert that the harm caused by drugs demands a rigorous response. Many in the West do not agree that drug offenses are among the most serious, but they do tend to concur with placing terrorism in this category. Hence, when Pakistan swiftly resumed executions in the wake of the Taliban massacre of children at the Army school in Peshawar in December 2014 and Egypt increased its use of capital punishment for terrorist offenses following the crushing of the Moslem Brotherhood, protests by Western governments were muted.

The largest democracy in the world-India-makes little use of the death penalty overall but remains committed to retaining it for terrorism. India's policy ${ }^{68}$ since the landmark case Bachan Singh v State of Punjab (1980) ${ }^{69}$ has been to reserve the death penalty for the 'rarest of rare', where the 'collective conscience' of a community may be shocked and where the offender is considered to be beyond rehabilitation. ${ }^{70}$ But the courts have been inconsistent, ${ }^{71}$ and the 'rarest of the rare' doctrine has not been a cure for arbitrariness in the infliction of the death penalty. ${ }^{72}$ Within the current climate of an international 'war on terror', the most heinous crimes are likely not to include the murder of a child or a wife, but acts of 'terrorism' howsoever defined. These offenses are usually committed by ethnic and religious minorities on foreign ground.

India has suffered from terrorist outrages due to religious and political conflicts within and with her neighbours, not least Pakistan. A recent Law Commission of India Report on the death penalty recommended its abolition for all offenses except terror offenses. The bulk of the 250-page Report made clear that the death penalty does not deter offenders any more than life imprisonment. It acknowledged that the Bachan Singh (rarest of rare) guidelines have failed to prevent death sentences from being 'arbitrarily and freakishly imposed', with no principled method existing to remove such arbitrariness, and with substantial evidence of the death penalty operating 'disproportionately against the socially and economically marginalized who may lack the resources to effectively advocate their rights'. However, the Law Commission

67 In 2014, the International Labour Office argued that 'there is an urgent need to address the socio-economic root causes of this hugely profitable illegal practice if it is to be overcome'. International Labour Organization, 'Profits and Poverty: The Economics of Forced Labour' (20 May 2014) $2<$ www .ilo.org/global/topics/forced-labour/publications/profits-of-forced-labour-2014/lang--en/index.htm> accessed 19 November 2018.

68 DT Johnson, 'The Death Penalty in India' in N Prabha Unnithan (ed), Crime and Justice in India (Sage 2013) 365-372.

${ }_{69}$ Bachan Singh v State of Punjab (1980) (2) SCC 684.

$70 \quad$ Machhi Singh and Others $v$ State of Punjab (1983) (3) SCR 413.

71 A Bindal and CR Kumar, 'Abolition of the death penalty in India: Legal, Constitutional, and Human Rights Dimensions' in R Hood and S Deva (eds), Confronting Capital Punishment in Asia (OUP 2013) 129.

${ }^{72}$ Bikram Jeet Battra, 'Lethal Lottery: The Death Penalty in India: A Study of Supreme Court Judgments in Death Penalty Cases, 1950-2006' (May 2008) <https:/www.amnesty.org/download/ Documents/52000/asa200072008eng.pdf $>$ accessed 15 June 2019; Surya Deva, 'Death Penalty in the 'Rarest of Rare' Cases: A Critique of Judicial Choice-making' in R Hood and S Deva (eds), Confronting Capital Punishment in Asia (OUP 2013) 238-286; Bikramjeet Batra, 'A Knotty Tale: Understanding the Death Penalty in India' in Lill Scherdin (ed), Capital Punishment: A Hazard to a Sustainable Criminal Justice System (Ashgate 2014) 213-228. 
stopped short of recommending total abolition. Instead, it urged the government to "take the first step towards abolition of the death penalty for all offences other than terrorism related offences... and waging war', crimes that clearly offend the 'collective conscience' of India today. $^{73}$

Not surprisingly, while death sentences continue to be imposed, somewhat arbitrarily, only one person has been executed for an 'ordinary' murder since 1995, while three men, all Muslims (Ajmal Kasab in 2012, Afzal Guru in 2013, and Yakub Memnon in 2015) were executed for their part in terrorist offenses. But although there have only been four executions in 20 years, a tiny number in a country of 1.2 billion people, minorities from within India or beyond her borders are most likely to languish in poor conditions on death row. ${ }^{74}$

\section{DISADVANTAGE UNDER RELIGIOUS LAWS}

Aside from terrorism laws, minorities may be sentenced to death for alleged hostility to political or religious dogma. Apostasy was rarely prosecuted until it became something of a political weapon with the new tide of resurgent Islam (following a long period of secularization in the Muslim world since the mid-nineteenth century), and contemporary political conflicts between the Middle East and the West. Apostasy is now punishable by death in Afghanistan, Iran and Saudi Arabia. Similarly, various Islamic governments have broadened and manipulated the definition of 'hirabah' (public terrorism) as a means of silencing political opposition. ${ }^{75}$

There is no inevitability to the interpretation of Shari' $\bar{a}$ law, allowing for arbitrariness in its imposition across borders. Indeed, as M Cherif Bassiouni, a leading scholar of Muslim criminal law, argues, the use of capital punishment in many Muslim countries has gone beyond Islamic religious requirements, because traditionalists and fundamentalists have been in the ascendancy rather than 'secular reformists and forward-thinking traditionalists'. ${ }^{76}$ Mohammed Habash, a Syrian scholar and Imam, has similarly argued that 'Islamic law has a plethora of safeguards against using the death penalty that are found in the Holy Qu'rān' limiting it to the most heinous crimes. ${ }^{77} \mathrm{He}$ therefore criticizes the 'ruthless and reckless' application of Shari' $\bar{a}$ law in Islamic states, such as Afghanistan, for adultery, corruption, heresy, sorcery and homosexuality, which 'are not necessarily punishable by death' in the Qu'rān. ${ }^{78}$

It appears that intersectionality operates within the Muslim world, where ethnic minority groups seem to be more vulnerable to harsher readings of Shari' $\bar{a}$ law. In Iran, there is an

73 Government of India, Law Commission of India, 'Report No. 262, The Death Penalty' (August 2015) 214, 215, 217s < https://lawcommissionofindia.nic.in/reports/report262.pdf > accessed 20 November 2018.

74 National Law University, Delhi, 'Death Penalty India Report, Executive Summary' 20 (6 May $2016)<$ https:/www.project39a.com/dpir>. For a larger discussion on terrorism offenses and drug offenses subject to the death penalty, see text accompanying nn 73-98 and 109-131 in Ch 2.

75 'Sharia Law and the Death Penalty' (Penal Reform International, July 2015) <https://www .penalreform.org/resource/sharia-law-and-the-death-penalty/> accessed 19 November 2018.

76 MC Bassiouni, 'Death as a Penalty in the Shari' $\bar{a}$ ' in P Hodgkinson and WA Schabas (eds), Capital Punishment: Strategies for Abolition (CUP 2004) 174, 176, 185.

77 M Habash, 'Islamic Visions for the Abolition of the Death Penalty' in L Scherdin (ed), Capital Punishment: A Hazard to a Sustainable Criminal Justice System (Ashgate 2014) 231.

78 ibid 234. 
over-representation of prisoners from ethnic groups such as Baluchis, Kurds and Arabs among those executed for ' moharebeh' offenses (defined as 'a person who fights God; someone who takes up arms in specific cases'). In 2016, at least 44 people were executed under moharebeh and 'corruption on earth' charges, 29 for their political or ideological affiliation. All of them belonged to ethnic or religious minorities..$^{79}$ In August 2016, 25 Sunni Muslim men-22 from Iran's Kurdish minority and three of Iraqi nationality - were executed in Iran for moharebeh offences, without advance notice of the mass executions being given to families and lawyers. ${ }^{80}$

Foreign nationals within Islamic states will be particularly vulnerable to execution because they are much less likely to benefit from pardon and compensation. Under Shari'ā, Qesas crimes, such as murder, do not require the death penalty to be imposed, as homicide is classified as an individual wrong, rather than a crime against the state.$^{81}$ While the family of a murder victim can demand a death sentence for retribution, they can also grant forgiveness and might offer a pardon in return for 'blood money' - compensation or forfeited rights of inheritance (diyya). In Iran, in 2016, the number of victims who chose forgiveness or blood money outnumbered those who chose the death penalty. ${ }^{82}$ The Saudi Arabian government 'does its utmost, before the execution of Qesas to convince the relatives of the victim to commute the Qesas into...Diyya' ${ }^{83}$ However, since Diyya depends on the family being able and willing to pay compensation, it is predominantly a privilege for wealthier groups, with rich defendants in places such as Pakistan escaping death while the poor are executed ${ }^{84}$ Only those able to influence the victim's relatives through power or money (or a combination of both), through kinship or friendship or through good fortune, succeed in obtaining a pardon.

In Saudi Arabia, it is not surprising to find that foreign workers, whose families are invariably poor and far away, are rarely protected from execution by Diyya ${ }^{85}$ Indeed, Amnesty International found that of 104 cases of prisoners who benefited from pardons between 2000 and 2008, just ten were foreign nationals. ${ }^{86}$ It is estimated that there are almost 400,000 Filipinos working in Saudi Arabia. Ten are on death row; none have been able to pay blood money to reduce their sentence. ${ }^{87}$

\footnotetext{
79 'Iran: Annual Report on the Death Penalty 2016' (n 40).

80 Amnesty International, 'Death Sentences and Executions 2016' (n 34) 22.

81 SC Hascall, 'Shari'ah and Choice: What the United States Should Learn from Islamic Law About the Role of Victims' Families in Death Penalty Cases' (2010) 44 J Marshall L Rev 1, 3-4.

82 'Iran: Annual Report on the Death Penalty 2016' (n 40).

83 Sheik Mohammed Ibn Ibrahim Al-Hewesh, 'Shari'a Penalties and Ways of Their Implementation in the Kingdom of Saudi Arabia' in Farouk Abdul Rahman Mourad and others (eds), The Effect of Islamic Legislation on Crime Prevention in Saudi Arabia. Proceedings of the Symposium Held in Riyadh from 9 to 13 October 1976 (Ministry of Interior, Saudi Arabia, Crime Prevention Research Centre, 1980)
} 377.

84 Habash (n 76) 236; Elliott Goat, 'Trading Justice for Money' (The Independent, 10 January 2015) $<$ https://www.independent.co.uk/news/world/asia/trading-justice-for-money-prisoners-on-pakistans -death-row-can-pay-off-their-victims-families-in-9966027.html> accessed 29 August 2017.

85 Amnesty International, 'Affront to Justice: Death Penalty in Saudi Arabia, 2008' (14 October 2008) 31-32 <https://www.amnesty.org/download/Documents/56000/mde230272008en.pdf $>$ accessed 19 November 2018.

86 Amnesty International, 'Killing in the Name of Justice' (n 53).

87 Allan Nawal, 'Issue for Duterte to Tackle: 10 Filipinos Are on Saudi Death Row' (Inquirer Net, 10 April 2017) <https:/globalnation.inquirer.net/154587/issue-for-duterte-to-tackle-10-filipinos-are-on -saudi-death-row> accessed 15 June 2019. 
There are, of course, exceptions. One Indian, Dubai-based businessman claims to have paid over three million US dollars in 'blood money' on behalf of 89 Indian adults and youths sentenced to death in the UAE, since 2010. This involved persuading the victims' families to accept his money in return for a pardon ${ }^{88} \mathrm{He}$ used his wealth for this purpose knowing that for most foreign nationals diyya is effectively inaccessible. ${ }^{89}$

\section{ATTEMPTS TO AMELIORATE DISADVANTAGE AND DISCRIMINATION}

Data on the disproportionate representation of death row of members of religious or ethnic minorities or foreign nationals suggests that the application of the death penalty has an unequal effect on members of such groups, and may, as a result, be contrary to article 6 of the ICCPR. ${ }^{90}$ States' laws and practices produce and compound disadvantage against minority groups and non-citizens while relying on them for a ready pool of cheap labor, creating a moral case- if not a legal one- - for measures to ameliorate disadvantage.

International standards and safeguards relating to capital punishment should apply to foreign nationals as well as those with full citizenship. However, they typically face discrimination, are arbitrarily and disproportionately affected by the death penalty because they are unfamiliar with the laws, have limited access to competent legal representation, may not understand the charges against them, nor be able to participate in their own defense, and may be denied free assistance from an interpreter to translate all relevant documents. ${ }^{91}$ This final section considers the various mechanisms through which foreign nationals might be protected and assisted both by their host state and by their nation state when exposed to the ultimate penalty. It considers if these mechanisms are sufficient to protect foreign nationals and where foreign nationals might be most vulnerable.

\section{VIENNA CONSULAR RIGHTS FOR FOREIGN NATIONALS}

The possibility of a foreign citizen in a retentionist country being disadvantaged was recognized in Article 36(1b) of the Vienna Convention on Consular Relations 1963, ratified by 167 nations. It provides that the competent authorities of a state in which a foreign national is 'arrested or committed to prison or to custody pending trial or is detained in any other manner'

88 Puja Changoiwala, 'For Indians on Death Row in the UAE, Reprieve Comes From an NRI Entrepreneur' (Firstpost, 4 June 2017) <https://www.firstpost.com/india/for-indians-on-death-row-in -the-uae-reprieve-comes-from-an-nri-entrepreneur-3513977.html $>$ accessed 15 June 2019.

89 For further discussion of the challenges created by the use of capital punishment within Islamic theology, see text accompanying nn 164-213 in Ch 17.

90 Human Rights Committee, 'General Comment on Article 6 of the International Covenant on Civil and Political Rights - Right to Life' CCPR/C/GC/R.36 (2 September 2015) para 46.

${ }_{91}$ UN Human Rights Council, 'Capital Punishment and the Implementation of the Safeguards Guaranteeing Protection of the Rights of Those Facing the Death Penalty’ A/HRC/30/18 (16 July 2015) 12. 
shall without delay ${ }^{92}$ inform the consular post of that person's state. Consular authorities must be allowed access to the detainee, whether by visit, telephone or video conference, or through correspondence. The State must also forward communication from the foreign national to the consular authorities, who must be allowed to assist, not least by providing access to competent counsel. They can help with the investigation of the case, including collating information for mental health defenses or mitigation, and they may intervene in trials when due process rights are breached. Consular assistance can be the only mechanism for securing reliable interpretation services, imperative for fair trial and pre-trial proceedings. Consular authorities are notified of developments in the case, such as impending court hearings and changes to the charge or transfer of the detainee to another location. It is also important that the State informs a family member, nominated by the detainee, of all relevant stages and decisions in the case. At a later stage, the consulate may also make representations to the clemency authority on behalf of the prisoner. ${ }^{93}$ Juvenile detainees should also be informed of their rights to communicate with a parent or other suitable adult that might stand in loco parentis before they are required to make statements or answer questions.

Access to consular services without delay aims to secure procedural equality between foreign nationals and citizens and is therefore a critical aspect of protection afforded to foreign nationals arrested for a criminal offense abroad, but particularly for those arrested for crimes that might result in a death penalty. Importantly, these rights cannot be circumvented by local legislation; domestic law or practice that restricts these rights would breach the Convention. The Inter-American Commission on Human Rights has found that when consular assistance is given, it can have a positive impact on the case. ${ }^{94}$ However, the fact that this practice has not been universally followed has led various international bodies to urge Member States that continue to use the death penalty to comply fully with their international obligations under Article $36 .{ }^{95} \mathrm{EU}$ guidelines on the death penalty remind states to ensure that 'anyone suspected of or charged with a crime for which capital punishment may be imposed has been informed of their right to contact a consular representative'. ${ }^{96}$ There is however some variation in state practices as regards the assistance given.

It might be thought that foreign nationals would fare best in the wealthiest retentionist democracy, and yet foreign nationals have been executed in the US without ever being informed

92 The importance of informing without delay - at the point of arrest or as soon as it is apparent or suspected that the detainee is a foreign national - has been confirmed by the International Court of Justice in its Avena ruling. Vienna Convention on Consular Relations (Vienna, 24 April 1963) 596 UNTS 261, 21 UST 77, TIAS No 6920, entered into force 19 March 1967.

93 Refusal to allow foreigners the power to seek clemency or commutation could amount to a violation of Art 6(4) of the Covenant. UN General Assembly, 'Report of the Special Rapporteur' (n 31) para 74.

94 I/A Comm'n on HR Reports cited in UN Economic and Social Council, 'Capital Punishment and the Implementation of the Safeguards Guaranteeing Protection of the Rights of Those Facing the Death Penalty' E/2015/49 (13 April 2015) para 98.

95 Most recently in the 'Yearly Supplement of the Secretary-General of the UN to his quinquennial report on capital punishment' of the Human Rights Council, 'Capital Punishment and the Implementation of the Safeguards Guaranteeing Protection of the Rights of Those Facing the Death Penalty’ A/HRC/36/26 (22 August 2017).

96 UN Human Rights Council, 'Question of the Death Penalty: Report of the Secretary General' A/ HRC/24/18, (1 July 2013) 52. 
of their right to consular assistance. Although the US ratified the Convention in $1969,{ }^{97}$ several court decisions have demonstrated that individual states in America's federal system can in practice choose not to be bound by this international treaty. Notorious cases include Angel Breard, a citizen of Paraguay, executed by the Commonwealth of Virginia in $1998,{ }^{98}$ and Karl and Walter LaGrand, German citizens who were executed in 1999;99 in both cases, the United States was found by the International Court of Justice (ICJ) to have failed to abide by its obligations to inform foreign nationals of their right to have their consulate informed of their detention. Most often it is Mexican migrants that are denied these rights. In 2004, the ICJ held that the US had violated its obligation under the Convention in 51 out of 52 cases (Avena and other Mexican nationals $)^{100}$ brought before the Court, and that the US should review, through the judicial process, the convictions and sentences imposed in each case. ${ }^{101}$ In response, in 2005, the US withdrew from the Optional Protocol to the Vienna Convention so that it would no longer be subject to adjudication by the ICJ. Since then Texas executed Mexican nationals Jose Ernesto Medellin, ${ }^{102}$ Humberto García Leal, Edgar Tamayo Arias and Hernandez Llanas (all Avena cases), executions held by the ICJ to be in breach of the United States' obligations under international law, ${ }^{103}$ and condemned by the Inter-American Commission on Human Rights, the Mexican Foreign Minister and by numerous other governments. ${ }^{104}$

A study carried out by Reprieve between 2009 and 2012 identified 134 foreign nationals on death rows in America, as well as 20 with dual (US and other) nationality. Of those 102 cases for which Reprieve was confident that it had undisputed data, in only five had there been Vienna Convention compliance. Of the four convicted by a federal court, only one had received appropriate Vienna Convention notice. The report states: 'Of those currently facing execution in state court, where there was a violation of the VCCR, not one... has received relief from a death sentence on this ground.' 105

97 Proclamation of Ratification, 21 UST 77, 185 (22 October 1969).

98 Breard v Greene 523 US 371 (1998).

99 LaGrand case (Germany v United States of America), Judgment, ICJ Rep 2001 (June 27). For further details on these cases, see Hood and Hoyle (n 3).

100 Avena and other Mexican Nationals (Mexico v United States of America (Avena)), ICJ Rep 12 2004 (March 31).

101 See further C Hoppe, 'Implementation of LaGrand and Avena in Germany and the United States: Exploring a Transatlantic Divide in Search of a Uniform Interpretation of Consular Rights' (2007) 18(2) European J Intl L 317-336.

102 Medellin v Texas 552 US 491 (2008).

103 See Request for Interpretation of the Judgment of 31 March 2004 in the Case concerning Avena and Other Mexican Nationals, General List No 139; Human Rights Council, 'Promotion and Protection of all Human Rights, Civil, Political, Economic, Social and Cultural Rights, Including the Right to Development: Report of the Special Rapporteur on Extrajudicial, Summary or Arbitrary Executions, Philip Alston' A/HRC/11/2/Add.5 (28 May 2009) 24-27.

104 'Foreign Nationals: Mexican Foreign Minister Appeals to Texas Officials About Upcoming Election' (Death Penalty Information Center) <https://www.deathpenaltyinfo.org/foreign-nationals -mexican-foreign-minister-appeals-texas-officials-about-upcoming-execution $>$ accessed 20 November 2018. Organization of American States, 'IACHR Condemns Execution of Humberto Leal García in the United States' (8 July 2011)

105 Reprieve, 'Honored in the Breach: The United States' Failure to Observe its Legal Obligations under the Vienna Convention on Consular Relations (VCCR) in Capital Cases' (November 2012) $2<$ https:// reprieve.org.uk/wp-content/uploads/2015/01/2013_02_26_PUB-VCCR-Report-WEB-VERSION-KEY -DOC.pdf $>$ accessed 15 June 2019. According to the US Death Penalty Information Center ${ }_{\mathfrak{R}}$ in January 
In 2016, foreign nationals were under sentence of death in Malaysia, Sri Lanka, Thailand, Vietnam, Ghana, Mauritiana, Nigeria, Zambia, China, Indonesia and in Saudi Arabia; in many cases for drug offenses. ${ }^{106}$ Not all will have received consular assistance. For the past few decades, concerns have been raised about the high number of migrant workers executed without being informed of their consular rights in Saudi Arabia. ${ }^{107}$ The UN Human Rights Committee found: 'In 2011, at least 79 people were reportedly executed in Saudi Arabia. Among them, many were migrant workers, 40 deprived of protection under the Vienna Convention and sentenced to death without respect of fair trial standards. ${ }^{108}$ Amnesty International put the figure for 2013 at 'at least 37' and estimated that 'at least 991' foreign nationals had been executed between 1985 and 2013, accounting for 'almost half' of the total number executed. Most of them 'have little knowledge of Arabic and are often denied adequate translation facilities'. ${ }^{109}$ Neither do they typically have access to a defense lawyer, nor are they informed of the progress of legal proceedings against them. ${ }^{110}$

Consular access is part of the law in Malaysia, ${ }^{111}$ and yet foreign nationals arrested there and detained on suspicion of offenses, including those which may result in a death sentence, have not always been offered their right to consular assistance in a timely fashion. Likewise, consular officers of other jurisdictions are not always informed of such arrests or detentions at the time of arrest. ${ }^{112}$ Most recently, in July 2017, a Malaysian national, Prabagaran Srivijayan, was executed in Singapore for drug trafficking although his case raised serious fair trial concerns. Months before, the Death Penalty Project in London and his legal team in Malaysia made an application for judicial review to the High Court of Malaysia on the basis that Malaysia had failed in its responsibility to protect the rights of its citizens abroad by declining to make diplomatic representations on Srivijayan's behalf. He was executed before the Malaysian Court of Appeal had delivered its judgment. ${ }^{113}$

\section{WHEN VIENNA CONVENTION RIGHTS FAIL}

While we know relatively little about compliance with the Vienna Convention other than in the US, it is clear that some states, including Malaysia and Saudi Arabia, are not taking

2014 there were, at a minimum estimate, as there is national registry, 141 foreign nationals on America's death rows, the largest number (59) from Mexico. Even when applying a less generous definition of the requirements imposed by the VCCR, DPIC found only seven cases of complete compliance out of more than 160 reported death sentences at first instance. 'Foreign Nationals and the Death Penalty in the US' (Death Penalty Information Center, 19 November 2018) < https://deathpenaltyinfo.org/foreign-nationals -and-death-penalty-us> accessed 15 June 2019.

106 Amnesty International, 'Death Sentences and Executions 2016' (n 34).

107 Amnesty International, 'Death Sentences and Executions 2013' (n 47).

108 UN Human Rights Council, 'Question of the Death Penalty' (n 95) para 38.

109 Amnesty International, 'Death Sentences and Executions 2013' (n 47).

110 A Ethirajan, 'Saudi Beheading of Eight Bangladesh Workers Condemned' (BBC News, 8 October

$2011)<$ https://www.bbc.co.uk/news/world-south-asia-15228607> accessed 21 August 2017.

111 Consular Relations (Vienna Convention) Act 1999, s 2(1).

112 Interview with staff at the Death Penalty Project London, August 2017.

113 'Imminent Execution of Malaysian National in Singapore' (The Death Penalty Project, 13 July 2017) <https://www.deathpenaltyproject.org/2017/07/13/imminent-execution-of-malaysian-national-in -singapore/> accessed 20 November 2018. 
seriously their obligation to protect the rights of all foreign nationals facing the death penalty. Furthermore, there is anecdotal evidence that many other countries in the Middle East and Asia, such as the UAE and Indonesia, are failing in this regard too. What then can people expect by way of assistance when they are charged with capital offenses on foreign soil and what are the wider obligations of our own governments to protect us and our fellow nationals from the death penalty?

Abolitionist states have responsibilities with regards to retentionist jurisdictions. First, they should not facilitate the use of the death penalty elsewhere through extradition or deportation of a person if they know there is a real risk of the imposition of the death penalty in that case. ${ }^{114}$ A retentionist state can only transfer a person in such circumstances if the requesting state adheres to all requirements imposed by international law. Second, abolitionist states must not cooperate and collaborate with retentionist jurisdictions, through financial support, training or intelligence-sharing, for example, if the assistance could amount to complicity in the death penalty. ${ }^{15}$ Research by Reprieve and Harm Reduction International suggests this has happened in Iran and Pakistan, ${ }^{116}$ and most recently Reprieve found that British assistance to justice and security institutions in Bahrain helped 'to prop up [its] death penalty system' ${ }^{117}$ Finally, states have responsibilities towards their own nationals on death row abroad, especially if they are detained in jurisdictions known not to honour their Vienna consular obligations. ${ }^{118}$

Again, rigorous empirical research is needed to establish what abolitionist (and retentionist) nations do in this regard, though there is some evidence that the European Union and its member states have made efforts to protect their own citizens from the death penalty. A recent example is provided by the case of Norwegian-British national, Joshua French, who was extradited to Norway, after years on death row in Congo during which time his mental health deteriorated significantly. This case, which took considerable efforts over many years by the government in Norway, the UK Foreign and Commonwealth Office and human rights organizations in the UK, most notably the Death Penalty Project, demonstrated the greater efficacy achieved by governments and NGOs working in cooperation. ${ }^{119}$

114 Human Rights Committee, Judge v Canada (Communication no 829/1998); Human Rights Committee, Al-Saadoon v UK. For a discussion of these cases, see Hood and Hoyle (n 3) ch 7; see also J Yorke, 'Europe's Inquiry in Extradition Cases: Closing the Door on the Death Penalty' (2004) 29(4) ELR 546.

115 For a sophisticated legal analysis of what it means to refrain from assisting the use of the death penalty abroad, see B Malkani, 'The Obligation to Refrain from Assisting the Use of the Death Penalty' (2013) 62 ICLQ 523-556.

116 Patrick Gallahue, Roxanne Saucier and Damon Barret, 'Partners in Crime: International Funding for Drug Control and Gross Violations of Human Rights' (Harm Reduction International, 2012) <https:// www.hri.global/files/2012/06/20/Partners_in_Crime_web1.pdf $>$ accessed 20 November 2018; Reprieve, 'European Aid for Executions: How European Counter-narcotics Aid Enables Death Sentences and Executions in Iran and Pakistan' (November 2014) <https://www.reprieve.org.uk/wp-content/uploads/ 2014/12/European-Aid-for-Executions-A-Report-by-Reprieve.pdf $>$ accessed 15 June 2019.

117 Reprieve, 'Britain's Cash and Bahrain's Firing Squads - 5 Things We've learned' (20 May 2017) $<$ https://www.reprieve.org.uk/death-penalty-around-world/the-stories/britains-cash-bahrains-firing -squads-5-things-weve-learned/> accessed 15 June 2019.

118 For further discussion on the practice of extradition in capital cases and the importance of non-complicity as the underlying rationale for seeking and obtaining assurances, see $\mathrm{Ch} 4$.

119 P Wijnen, 'Solberg: Joshua French Has Arrived in Norway' (Norway Today, 17 May 2017) $<$ https://norwaytoday.info/news/solberg-joshua-french-arrived-norway/> accessed 15 June 2019; 'Norwegian-British prisoner released from death row in DRC amid growing health concerns' (The Death 
There are limits to what abolitionist governments will do for their own citizens. For example, while consular assistance has been given to Lindsey Sandiford, the British grandmother on death row in Indonesia, the British government refused to fund her appeal. This was found to be lawful by the UK Supreme Court. ${ }^{120}$ The Australian government too has faced criticism. Until 2009, Australian authorities could assist other countries with investigations into criminal offenses by Australian nationals even if the charges might result in a death penalty. Public outcry following such assistance in the case that resulted in the prosecution of the 'Bali Nine' in 2006 resulted in federal police guidance on assistance. However, recent research has found that Australia still risks being in breach of its international law obligations to protect its own citizens from human rights abuses abroad in the context of the death penalty. ${ }^{121}$ Indeed, Gerry and Sherwill have argued that 'Australia is effectively complicit in drug executions-in violation of international human rights law and its own stance as an abolitionist nation...' ${ }^{122}$

Migrant workers within states that have ratified the International Convention on the Protection of the Rights of All Migrant Workers and Members of Their Families have certain protections, but to date only 49 states have done so (for example, the US has not ratified it). Thus far, countries that have ratified the Convention are primarily countries of origin of migrants (such as Mexico, Morocco and the Philippines) that are more likely to introduce other measures to assist their own citizens. Mexico, for example, has, since 2000, operated a government funded Capital Legal Assistance Programme to provide Mexican citizens abroad with lawyers at pre-trial, appellate and post-conviction proceedings. Between 2000 and 2014, it intervened in over 1000 cases, leading to the prevention or reversal of the death penalty in 878 cases. ${ }^{123}$ And the Philippines has legislated to ensure its migrant workers abroad receive legal assistance in capital (and non-capital) cases. ${ }^{124}$

Some retentionist jurisdictions, such as Indonesia, have also ratified the Convention. The beheading in 2011 of an Indonesian overseas domestic worker, who had been tried without a defense lawyer, led the government to set up a taskforce to protect Indonesian migrant workers facing the death penalty abroad. ${ }^{125}$ The Task Force on Migrant Worker Protection negotiated clemency on behalf of 110 Indonesian citizens in 2012 and claims to have been instrumental in the commutation of death sentences for 37 workers in Saudi Arabia, 14 in Malaysia, 11 in China and one in Iran. ${ }^{126}$ The Indonesian Ministry of Foreign Affairs estab-

Penalty Project, 18 May 2017) <https://www.deathpenaltyproject.org/2017/05/18/norwegian-british -prisoner-released-from-death-row-in-drc-amid-growing-health-concerns/> accessed 15 June 2019.

120 M Brown, 'Lindsay Sandiford: Five years on ...' (GazetteLive, 31 May 2017) < https://www.gazettelive .co.uk/news/teesside-news/lindsay-sandiford-five-years-on-13114381> accessed 30 August 2017.

121 Felicity Gerry QC and Narelle Sherwill, 'Submission to the Joint Standing Committee on Foreign Affairs, Defence and Trade: Australia's Advocacy for Abolition of the Death Penalty' (1 October 2015). To access Parliament of Australia Human Rights Sub-Committee inquiry Report and other Submissions, see < https://www.aph.gov.au/Parliamentary_Business/Committees/Joint/Foreign_Affairs_Defence_and _Trade/Death_Penalty/Submissions $>$ accessed 21 August 2017.

${ }_{122}$ F Gerry and N Sherwill, 'Human Trafficking, Drug Trafficking, and the Death Penalty' (2016) 3 Indonesia L Rev 265, 270.

123 UN General Assembly, 'Report of the Special Rapporteur' (n 31) para 108.

124 ibid.

125 UN Human Rights Council, 'Question of the Death Penalty' (n 95) para 38.

126 O Robertson and R Brett, 'Lightening the Load of the Parental Death Penalty on Children' (Quaker United Nations Office, 2013) <www.quno.org/sites/default/files/resources/Lightening\%20the \%20Load.Web_.EN_.pdf> accessed 20 November 2018. 
lished the Legal Aid and Protection of Indonesians Overseas Unit, which has intervened in 247 cases of Indonesians under sentence of death abroad. ${ }^{127}$ Indeed, it has claimed to have been successful in removing 110 of the 200 or so Indonesians on death row abroad and in April 2014 paid a substantial portion of blood money to save the life of an Indonesian maid in Saudi Arabia. ${ }^{128}$ Most recently, in November 2018, the Indonesian government expressed outrage after Saudi Arabia executed an Indonesian domestic worker who was convicted of killing her Saudi employer, though the maid claimed to have been defending herself from being raped and the Indonesian embassy in Saudi Arabia had not been notified that her execution was imminent. ${ }^{129}$ Of course, it has been pointed out that Indonesia's recent vehement and effective advocacy for clemency for its citizens who are sentenced to death abroad is at odds with the continued application of the death penalty at home, and international efforts might effectively be directed at agitating around this moral ambivalence. ${ }^{130}$

Malaysia has yet to institute a similar government-backed scheme to its neighbor, and recently, a Malaysian national on death row in Singapore sought judicial review to compel the Malaysian government to institute legal action against Singapore at the ICJ, arguing that he did not receive a fair trial in Singapore. ${ }^{131}$ Furthermore, those countries who make the most use of migrant labor, and who retain the death penalty for many offenses - such as Saudi Arabia, Qatar, Kuwait and the United Arab Emirates - have been stigmatized for providing inadequate protection for migrants. They have neither signed nor ratified the Convention. ${ }^{132}$

While some governments - even retentionist ones-have put in place mechanisms for supporting their citizens abroad, it is often only NGOs and campaigning lawyers who provide assistance for foreign nationals in other jurisdictions. For example, the London-based NGOs, Reprieve and the Death Penalty Project, work with foreign nationals and with local lawyers to provide legal assistance and advice at various stages of the legal and clemency processes. Their clients originate from countries including Britain, Bulgaria, Fiji, Nigeria, Peru, South Africa, Uganda, Zambia and the Gulf states. The Death Penalty Project recently helped to

127 A Fenia Arimbi, '247 Indonesians Abroad Under Threat of Death Penalty' (Antara News, 20 September 2013) < https://www.antaranews.com/en/news/90806/247-indonesians-abroad-under-threat -of-death-penalty> accessed 15 June 2019.

128 D McRae, 'Staying the Executioners' Guns?' (Inside Indonesia, 3 February 2013) <https://www .insideindonesia.org/feature-editions/staying-the-executioners-guns $>$ accessed 21 August 2017. In Saudi Arabia and other countries, the Indonesian government has also taken the unusual step of spending public funds for the payment of 'blood money' to secure pardons of Indonesians on death row abroad. See 'Saudi Arabia: "Blood Money” Payment Spares Indonesian Maid from Execution' (Hands Off Cain, 26 June 2011) <www.handsoffcain.info/archivio_news/201106.php?iddocumento=15308203\&mover=0> accessed 15 June 2019.

129 'Fury as Saudi Arabia Executes Indonesian Maid Tuti Tursilawati Without Warning' (South China Morning Post, 1 November 2018) <https://www.scmp.com/news/asia/southeast-asia/article/2171121/ fury-saudi-arabia-executes-indonesian-maid-tuti-tursilawati> accessed 15 June 2019.

130 K Vaswani, 'Indonesia's New Appetite for Execution' (BBC News, 8 February 2015) <https:// www.bbc.co.uk/news/world-asia-31124858> accessed 15 June 2019.

131 R Anand, 'Death Row Inmate's Judicial Review Bid Not Interfering with Singapore Affairs, Says Lawyer' (Malaymail online, 16 January 2017) <https:/www.themalaymailonline.com/malaysia/article/ death-row-inmates-judicial-review-bid-not-interfering-with-singapore-affair\#hfGL5Dpy3HvBGvFM $.97>$ accessed 15 June 2019.

132 'Saudi Arabia/GCC States: Ratify Migrant Rights Treaty' (Human Rights Watch, 10 April 2003) $<$ https:/www.hrw.org/news/2003/04/10/saudi-arabia/gcc-states-ratify-migrant-rights-treaty> accessed 15 June 2019. 
overturn the death sentences of two Bulgarian nationals sentenced in Malaysia in 2015. It also works with psychiatrists, doctors, chemists and other forensic experts to ensure that the rights of foreign nationals are fully realized. ${ }^{133}$ Reprieve has worked with Justice Project Pakistan, to try to help Pakistani migrant workers on death rows abroad.

As discussed above, while Saudi Arabia applies the death penalty disproportionately to foreign nationals, it denies them adequate assistance. Their countrys embassies and consulates are not promptly informed of their arrest or even of their executions, and interpretation services are not routinely made available to non-Arabic speaking defendants, without which they cannot exercise effectively their rights at all stages of the judicial process. Indeed, the Law of Criminal Procedure in Saudi Arabia does not appear to recognize this necessity, making provisions for such services only at the trial stage. Given the secrecy that shrouds interrogations, adequate and independent interpretation facilities at this stage are crucial for a fair trial.

According to the Justice Project Pakistan, about 2400 of the 8500 Pakistani citizens in jails worldwide are in Saudi Arabia. As Pakistan lacks a codified policy on consular support for its citizens imprisoned abroad, many face execution without assistance, with Saudi Arabia executing at least 40 since $2014 .{ }^{134}$ In response to a Lahore High Court petition filed by Justice Project Pakistan on behalf of ten families of Pakistani migrants facing the death penalty in Saudi Arabia, the Pakistani government submitted guidelines for dealing with Pakistani prisoners abroad. However, these are not widely disseminated, and so most prisoners are not aware of their rights and are not receiving adequate support from their government. ${ }^{135}$ The petition had argued that by failing to support the prisoners, the Pakistani government had not met its obligations to its citizens under Pakistan's constitution and international human rights instruments. It also claimed that Pakistan was not effectively regulating OEPs, was violating the Vienna Convention by failing to exercise its consular rights and had 'failed to enter into any bilateral agreements to facilitate consular services to its detained citizen as agreed under the Treaty of Friendship between Saudi Arabia and Pakistan'. ${ }^{136}$

The Justice Project Pakistan gathered evidence that the Pakistani migrant workers had been denied a fair trial and had been deprived of their rights to appeal and of access to families. They had also been tortured in pursuit of 'confessions' and denied access to lawyers and impartial translators. Since the case was filed, six of the prisoners have been executed, some without notice, and their bodies were not transferred to their home country, as is customary for followers of Islam.

Nevertheless, a number of positive outcomes resulted from this case, including: the formulation and implementation of a unified Policy on Consular Support for imprisoned Pakistanis and those facing execution; representation for detained migrant workers in Gulf countries to

133 'Two Bulgarian Nationals Saved from Execution in Malaysia' (The Death Penalty Project, 14 February 2017) <https://www.deathpenaltyproject.org/news/2662/two-bulgarian-nationals-saved-from -execution-in-malaysia/> accessed 15 June 2019.

134 'Prisoners Abroad' (Justice Project Pakistan) < https://www.jpp.org.pk/prisoners-abroad/> accessed 30 August 2017.

135 ibid.

136 Justice Project Pakistan, 'Pakistani Migrants Facing the Death Penalty in Gulf Countries' (21-23 June 2016) <https://congres.abolition.fr/wp-content/uploads/2016/06/Presentations_Migrants -and-minorities.pdf $>$ accessed 20 November 2018 (presentation to the 6th World Congress Against the Death Penalty, Oslo). 
secure access to due process and ensure extradition to Pakistan; a review of existing regulatory framework for emigration of Pakistani migrant workers to minimize risks to citizens seeking employment opportunities abroad and accord adequate safeguards for the protection of fundamental rights; the registration of criminal charges against those responsible for entrapment and forced narcotics smuggling resulting in wrongful convictions and executions; and the repatriation of bodies of Pakistani prisoners executed in Gulf countries. ${ }^{137}$

A government shamed into action by an effective NGO will sometimes make efforts to better protect its citizens, and if some recalcitrant states refuse to honor their international obligations towards foreign nationals in their own jails, the burden of protection will need to fall to the governments who have a duty of care towards their own citizens while abroad. As the UN has made clear:

If it can empirically be shown that the provision of consular assistance can materially diminish the likelihood of the imposition of a death sentence (and the statistics made available by Governments with specialist programmes suggests that this is the case), then a Government that, when notified, does not take all reasonable steps to provide adequate consular assistance can arguably be said to have failed in its duty of due diligence to protect its nationals from arbitrary deprivations of life. ${ }^{138}$

Malkani goes further. While acknowledging that international law accepts that diplomatic protection is a discretionary matter for states, he argues that:

If...it can be inferred that a deliberate omission to provide assistance comes with it constructive knowledge on the part of the home State that it is making the imposition of the death penalty likelier...there is a legitimate expectation that States will assist their nationals who are facing the death penalty abroad, and that domestic courts should take action if and when the relevant domestic authorities refuse to provide protection without giving sufficiently good reasons. ${ }^{139}$

\section{PURSUING KNOWLEDGE AT THE INTERSECTIONS OF RACE, RELIGION AND CITIZENSHIP}

This chapter makes clear that those who care about discrimination and disadvantage in the administration of the death penalty worldwide need to pay more attention to citizenship. This is true not only of legal representatives, NGOs and governments, but also of academic lawyers and criminologists who research the death penalty. Bosworth's scholarship has demonstrated the theoretical poverty of explanations of criminal justice discrimination that do not take account of this issue. ${ }^{140}$ While her work focuses on the detention of migrants from the global south in the global north, the profound disadvantage exposed here is mirrored on death rows, especially in the Middle East and across Asia. Academic analysis must now begin to accommodate the intersecting inequalities which position certain social groups subordinately, confirming their marginalization and exclusion through race, class, ${ }^{141}$ and, of course, citizenship.

137 ibid.

138 UN General Assembly, 'Report of the Special Rapporteur' (n 31) para 109.

139 Malkani (n 114) 536.

140 M Bosworth, 'Border Criminology: How Migration is Changing Criminal Justice' in M Bosworth, C Hoyle and L Zedner (eds), The Changing Contours of Criminal Justice (OUP 2016).

141 Phillips and Webster (n 25) 3. 
Little is said above about gender, not least because outside of the US we know little about women charged with capital offenses. The data are thin and assumptions at this stage must be tentative. Yet compare the media interest in the rather unusual case of Lindsay Sandiford, the white British woman on death row in Indonesia on drug trafficking charges - about whom there are many sympathetic articles - with the inattention towards women executed in Afghanistan for adultery or in Saudi Arabia for retaliatory violence against their traffickers. Qualitative analysis of their experiences would likely suggest that in some contexts gender might prove to be a protective characteristic, while in others an aggravating factor. Clearly, an intersectional analysis of capital punishment would need to take account of the ways in which gender might intersect with race, religion and citizenship.

Across Europe over the past two decades, anti-migrant discourse has risen in popular culture and produced a new form of exclusionary politics. Part of the 'demonizing' of migrants has arisen from a desire to preserve 'economic prosperity and national identity'. ${ }^{142}$ While this is not founded in classic 'racism' as might be applicable to studies of the treatment of African Americans on death row in the US, in an era of xenophobia, non-citizens are segregated and excluded through immigration policies, gradual changes to welfare provisions, and through the criminal justice system, which over-polices and imposes harsher penalties on non-citizens while simultaneously failing to provide adequate legal protection. There is no reason to believe that these exclusionary politics are confined to the abolitionist jurisdictions of Europe; indeed, media reports suggest they also play out in the privileged countries of the Middle East and Asia that rely on migrant labor, yet fail to protect those migrants both from crime and the excesses of punitive and discriminatory justice systems.

Academic research has yet to investigate this subject, and as such, this chapter is a call to arms. As well as developing a theoretical framework derived from the concept of intersectionality, we need more and better data, and rigorous analysis. Parmar makes clear that, '[o]verlapping concepts such as race, ethnicity and nationality remain unaddressed [with] a lag between the lived realities of minority ethnic groups and criminological academic scholarship'. ${ }^{143}$ Though her own research provides an exception to this rule, ${ }^{144}$ her observation that criminology has failed fully to appreciate the complex relationships between different identities and how they play out in different countries of the world is highly pertinent to the discussion above. Death penalty scholarship needs to pay much closer attention to the impact of citizenship on people's vulnerability to capital punishment. It should adopt the lessons of intersectionality and foster empirical research among hard to reach populations in the Middle East and Asia.

${ }_{142}$ L Fekete, A Suitable Enemy: Racism, Migration and Islamophobia in Europe (Pluto Press 2009) 19.

143 A Parmar, 'Intersectionality, British Criminology and Race: Are We There Yet?' (2017) 21 Theo Crim 35, 36.

144 A Parmar, 'Stop and Search in London: Counter-terrorist or Counter-productive?' (2011) 21 Policing \& Society 369-382. 